\title{
PEMBELAJARAN SENI TARI \\ DALAM MENGHADAPI TANTANGAN REVOLUSI INDUSTRI 4.0
}

\author{
Tresna Maya Sofa \\ Fakultas Bahasa dan Seni, Universitas Negeri Yogyakarta \\ Email: tresna.maya.sofa@uny.ac.id
}

\begin{abstract}
Abstrak
Kemajuan dunia teknologi yang ditandai dengan revolusi industri 4.0 memudahkan setiap individu memperoleh dan membagikan informasi dari dan ke berbagai sumber. Keadaan ini secara langsung memberikan dampak bagi perkembangan dunia pendidikan di Indonesia. Salah satu dampak positif dari revolusi industri 4.0 yakni munculnya pembelajaran berbasis sistem elektronik atau e-learning yang memberikan kemudahan bagi siapa saja untuk melakukan pembelajaran tanpa dibatasi oleh ruang dan waktu. Hal ini tentu memberikan kemudahan dan keuntungan bagi para pendidik dan peserta didik dalam menyesuaikan kegiatan pembelajaran dan kebutuhan belajar setiap peserta didik. Namun, dalam proses pembelajaran seni tari, nampaknya perlu banyak menyesuaikan diri dengan keberadaan e-leraning ini, baik dari segi sarana dan prasarana, maupun konten pembelajaran. Hal ini mengingat seni tari merupakan pembelajaran yang melibatkan kemampuan dan kreativitas berolah gerak. Oleh karena itu maka, dibutuhkan pemikiran dan persiapan yang matang dalam menyediakan konten, meliputi sumber belajar dan aktivitas pembelajaran yang akan ditawarkan dalam e-learning. Berdasarkan hal tersebut maka, artikel ini akan dibahas mengenai karakteristik pembelajaran 4.0, konsep dan komponen pembelajaran berbasis e-learning dan argumen mengenai kesiapan dan langkah-langkah pembelajaran seni tari dalam menghadapi dunia pembelajaran baru yakni e-learning.
\end{abstract}

Kata kunci: Revolusi Industri 4.0, e-Learning, pembelajaran seni tari

\section{LEARNING OF ARTS IN FACING INDUSTRIAL REVOLUTION 4.0}

\begin{abstract}
The progress of the world of technology which is marked by the industrial revolution 4.0 makes it easy for individuals to obtain and share information from and to various sources. This situation directly impacts the development of education in Indonesia. One positive impact of the industrial revolution 4.0 is the emergence of electronic-based learning systems or e-learning that makes it easy for anyone to do learning without being limited by space and time. This certainly provides convenience and benefits for educators and students in adjusting the learning activities and learning needs of each student. However, in the process of learning dance, it seems that it is necessary to adapt to the existence of this e-learning, both in terms of facilities and infrastructure, as well as learning content. This is because dance is a learning process that involves the ability and creativity to exercise. Therefore, careful thought and preparation are needed in providing content, including learning resources and learning activities that will be offered in e-learning. Based on this, this article will discuss the characteristics of learning 4.0, the concepts and components of e-learning based learning and arguments about the readiness and steps of learning dance in facing the new learning world, e-learning.
\end{abstract}

Keywords: Industrial Revolution 4.0, e-Learning, Dance Learning 


\section{PENDAHULUAN}

Dunia mengalami banyak perubahan kemajuan secara cepat dan bertahap dari masa ke masa. Perubahan kehidupan yang cepat, bertahap dan berinteraksi tentu berdampak pada perubahan sistem lingkungan alam, sosial-budaya, ekonomi, hukum, dan bahkan perubahan sistem tataan nilai kehidupan. Kemajuan ilmu pengetahuan dan teknologi menjadikan alam secara optimal dapat diolah dan dipergunakan oleh manusia. Begitupun sosial-budaya, ilmu dan teknologi memberikan kemudahan berinteraksi dan berkomunikasi tanpa batas ruang dan waktu. Keberadaan teknologi membantu perekonomian dunia seperti halnya perdagangan global yang lebih praktis efektif dan efisien. Adapun dampak kemajuan ilmu pengetahuan dan teknologi dalam sistem hukum, contoh sederhananya mempermudah proses penegakan hukum dengan bantuan alatbukti berbasis teknologi dan masih banyak contoh sederhana lainnya yang mungkin tidak disadari mampu mempermudah aktivitas kita sehari-hari.

Seperti yang sedang banyak dibahas saat ini, dunia sedang dihadapi era disrupsi 4.0 atau dikenal dengan revolusi industri 4.0. Perubahan tersebut juga dirasakan oleh Indonesia sebagai salah satu negara berkembang di dunia. Perubahan diberbagai lini kehidupan mulai terasa, di mana adanya sistem komputerisasi berbasis internet yang memudahkan setiap aktivitas individu. Seiring perkembangan zaman yang begitu cepat, berbagai perubahan terus dilakukan untuk menyesuaikan diri dalam mengahadapi dunia baru. Tjandrawinata (2016) mengungkapkan bahwa kemajuan teknologi memungkinkan terjadinya otomatisasi hampir di semua bidang. Teknologi dan pendekatan baru yang mengagungkan dunia fisik, digital, dan biologi secara fundamental akan mengubah pola hidup dan interaksi manusia. Berdasarkan pendapat tersebut maka dapat disimpulkan kehidupan manusia di era 4.0 ini mengubah pola dan cara aktivitas manusia mencakup ruang lingkup, kompleksitas dan transformasi dari cara atau pola kehidupan sebelumnya. Semua kegiatan akan lebih mudah dilakukan dengan hanya mengandalkan pemanfaatan teknologi berbasis internet.

Begitu pula pendidikan di Indonesia terus menyesuaikan diri di era revolusi industri 4.0. Berbagai aktivitas pembelajaran mulai beralih dari yang konvensional menuju pendekatan yang modern berbasis internet. Sanusi (2014) mengungkapkan sebagai berikut:

"Belajar dan belajar-mengajar serta sistem pendidikan memiliki hubungan dengan kekakayaan alamnya yang tersedia. Faktorfaktor alam yang ada dapat mendukung atau membatasi bentuk dan usaha bisnis dan perekonomian setempat, hubungan dan kegiatan sosial setempat, dan juga macam keterampilan, aturan hukum, serta cara-cara kerja tekniknya. Jadi, itu semuamemiliki hubungan pengaruh timbal balik dengan sistem pembelajaran."

Pendapat Sanusi tersebut menegaskan bahwa perkembangan yang terjadi pada lingkungan tempat dimana dilakukannya proses belajar mengajar akan mempengaruhi kegiatan pembelajaran. Pengaruh tersebut dapat mendukung capaian dari proses pembelajaran yang diharapkan atau bahkan dapat menghambat dan membatasi proses pembelajaran. Oleh sebeb itu maka, kondisi lingkungan dengan pembelajaran memiliki hubungan timbal-balik satu sama lain.

Pendapat lain datang dari Trilling dan Fadel (2009) yang mengungkapkan bahwa pembelajaran di abad 21 berorientasi pada gaya hidup digital, alat berpikir, penelitian pembelajaran, dan cara kerja pengetahuan. Berdasarkan pendapat tersebut maka, karakteristik pembelajaran di era 4.0 ini lebih memudahkan setiap individu dalam mengases berbagai informasi dari berbagai sumber tanpa batasan ruang dan waktu. Hal ini tentu saja memungkinkan pembelajaran dapat dilakukan kapan saja dan di mana saja tanpa harus adanya kegiatan tatap muka antara tenaga pendidik dan peserta didik di dalam kelas. Karakteristik lainnya adalah pembelajaran mandiri, dimana peserta didik dengan bebas menentukan sendiri materi yang akan dia pelajari sesuai dengan kebutuhannya. Kemudahan-kemudahan 
tersebut diperoleh karena pembelajaran era 4.0 berbasis internet atau ICT (Internet Communication Technology).

Pembelajaran berbasis internet atau istilah lainnya e-learning pada dasarnya tidak berbeda dengan pembelajaran konvensional. Pada pembelajaran berbasis internet juga dibutuhkan konten-konten pembelajaran seperti halnya sumber belajar dan aktivitas pembelajaran. Sumber-sumber belajar seperti materi atau bahan ajar dibuat dalam bentuk multimedia (teks, gambar animasi, video) atau dapat juga berupa lembar presentasi), hal ini bertujuan untuk mempermudah para peserta didik dalam belajar dan tentunya lebih menarik. Adapun perangkat pembelajaran sebagai pendukung seperti kurikulum, silabus, RPP dan RPH tetap dibutuhkan dalam pembelajaran e-learning sebagai acuan dalam pembelajaran. Materi dan perangkat bembelajaran tersebut tentu membutuhkan sebuah tempat penyimpanan yang nantinya akan mudah diakses oleh para peserta didik (Susilawati, 2017: 128). Tempat penyimpanan dalam e-leraning berupa link atau situs yang dapat mewadahi dan mempermudah para peserta didik untuk mengasesnya dimana saja dan kapan saja.

Untuk menghasilkan lulusan yang kompetitif di era revolusi industri 4.0 dibutuhkan sumber literasi baru, tidak hanya terpaku pada membaca, menulis dan matematis yang biasa dan lama. Fitriani dan Aziz (2019, hlm. 101) mengungkapkan bahwa tugas dunia pendidikan saat ini melalui proses pembelajaran bukan hanya menekankan pada penguatan literasi lama, tetapi secara stimulan mengokohkan pada penguatan literasi baru yang menyatu dalam penguatan kompetensi bidang ilmu dan keahlian/profesi. Berdasarkan pendapat tersebut maka, pada era disrupsi ini dibutuhkan keterampilan dan kemampuan menguasai literasi baru yang akan menunjang ketercapaian kompetensi bidang ilmu dan profesinya.

Adapun literasi baru meliputi, literasi data, literasi teknologi dan literasi manusia sangatlah dibutuhkan dalam mempersiapkan diri baik sebagai tanaga pendidik maupun peserta didik untuk dapat berkompetisi di era 4.0. Literasi data meliputi kemampuan untuk membaca, menganalisism dan menggunakan informasi (big data) di dunia digital. Literasi teknologi adalah kemampuan untuk dapat memahami dan menggunakan mesin, aplikasi teknologi (coding, artificial intellegence, \& engineering principles) sesuai dengan cara kerja dan kebutuhannya. Sementara Literasi manusia adalah kemampuan untuk menjadi manusia seutuhnya dalam pengertian yang humanities, mampu berkomunikasi dengan baik, dan mengembangkan diri agar dapat berfungsi dilingkungan manusia.

Aktivitas pembelajaran e-leraning tidak jauh berbeda dengan pembelajaran tatap muka di kelas pada umumnya seperti halnya kegiatan diskusi, tanya jawab, forum, pemberian tugas, dan kuis. Namun, aktivitas tersebut dilakukan menggunakan media komputer berbasis internet yakni dengan dilakukan chatting antara tenaga pendidik dan peserta didik, maupun peserta didik dengan peserta didik. Vicon atau video conference dilakukan untuk menghadirkan tatap muka antara tenaga pendidik dan peserta didik atau peserta didik dengan peserta didik melalui media internet. Maka, sebenarnya tidak banyak perbedaan dengan pembelajaran konvensional hanya saja yang membedakan cara tenaga pendidik dan peserta didik dalam melakukan proses pembelajaran.

Pembelajaran berbasis internet ini memang memberikan kemudahan, khususnya bagi mata pelajaran yang bersifat teori akan tetapi mengalami sedikit kendala mana kala pembelajaran itu lebih mengarah pada pembelajaran bersifat praktikum. Salah satu contohnya adalah pembelajaran seni tari, yang merupakan pembelajaran praktik. Sepintas memang terlihat tidak ada masalah yang berarti, namun ada hal yang harus benar-benar dipersiapkan terkait sistem pembelajaran dan penilaian praktikum.

\section{PEMBAHASAN}

Pendidikan 4.0 yang sedang digalakan akhir-akhir merupakan bagian dari penyesuaian diri terhadap perkembagan industri dan 
teknologi era 4.0 dengan mengadaptasi dan mengedepankan pemanfaatan teknologi sebagai bagian dalam kegiatan pembelajaran. Hal ini seperti dipaparkan oleh Lase (2019) bahwa pendidikan 4.0 adalah respons terhadap kebutuhan revolusi industri 4.0 di mana manusia dan teknologi diselaraskan untuk menciptakan peluang-peluang baru dengan kreatif dan inovatif.

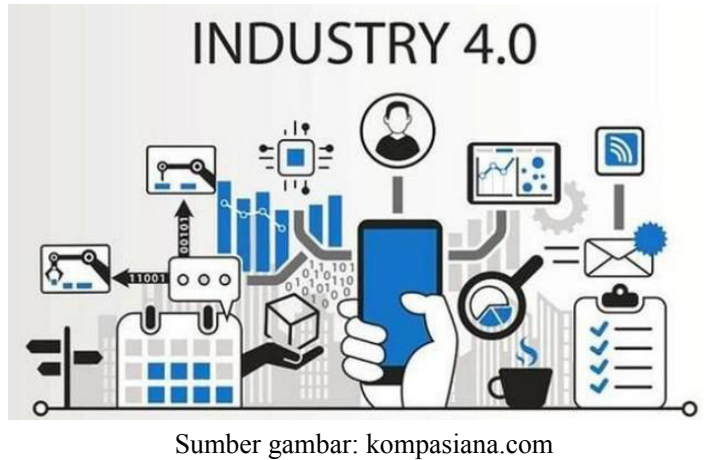

Pendapat lain datang dari Fisk (2017) berpendapat bahwa "that the new vision of learning promotes learners to learn not only skills and knowledge that are needed but also to identify the source to learn these skills and knowledge." Berdasarkan pendapat Fisk tersebut bahwa visi dalam pembelajaran di era baru ini lebih menitik beratkan pada cara siswa dalam mencari dan menggali sumber-sumber pembelajaran, sehingga sumber belajar tidak hanya terpaku pada satu sumber. Lebih lanjut Fisk (2017) dalam Lase (2019) mengungkapkan ada sembilan trend atau kecenderungan terkait pada pendidikan 4.0, diantaranya sebagai berikut:

Pertama, mengenai waktu dan tempat belajar. di mana pada era pendidikan 4.0 pembelajaran dapat dilakukan dimana saja dan kapan saja tidak harus di dalam kelas dengan waktu yang sudah ditentukan seperti pada pembelajaran biasanya. Keleluasaan waktu dan tempat belajar ini tentu dilakukan dengan bantuan teknologi atau dikenal dengan pembelajaran daring (online) atau e-learning, dengan demikian siswa akan memiliki lebih banyak kesempatan untuk belajar pada waktu dan tempat yang berbeda.
E-learning memfasilitasi dan memberikan kesempatan kepada peserta didik untuk pembelajaran jarak jauh dan mandiri. Fisk (2017) dalam Lase (2019) menyatakan trend yang kedua yaitu, pembelajaran individual. Adapun yang dimaksud dengan pembelajaran individual ialah siswa akan belajar sesuai dengan kemampuannya dalam melewati setiap kompetensi yang diberikan. Siswa yang belum mampu melewati tahapan kompetensi tidak dipaksakan untuk melangkah pada tahapan kompetensi selanjutnya melainkan diberikan kesempatan untuk mengulang kembali hingga ia mampu melewati dengan baik. Hal ini berdampak pada rasa percaya diri siswa dalam menyelesaikan setiap tugas kompetensi yang diberikan. Selain itu guru atau tenaga pendidik dapat melihat dan mengamati siapa saja siswa atau peserta didik yang memerlukan perhatian khusus pada setiap kompetensi atau mata pelajaran.

Pada trend ketiga Fisk (2017) dalam Lase (2019) mengungkapkan bahwa, siswa diberikan kebebasan memilih dalam menentukan bagaimana mereka akan melakukan proses pembelajaran. Kebebasan tersebut meliputi penggunaan alat, teknologi dan hal lainnya yang membantu proses pembelajaran dan mencapai tujuan pembelajaran yang diharapkan. Selanjutnya trend keempat menurut Fisk (2017) adalah pembelajaran berbasis proyek. Pembelajaran berbasis proyek dimaksudkan agar siswa dapat mengasah dan menerapkan keterampilannya dalam setiap kondisi. Pembelajaran berbasis proyek ini menurut Fisk dapat dimulai pada siswa sekolah menengah. Hal ini disebabkan pada siswa sekolah menengah sudah harus diajarkan keterampilan dalam mengorganisasikan suatu hal, kolaborasi dan manajemen waktu yang dapat berguna bagi siswa dalam akademik dan karirnya mendatang.

Trend kelima Fisk (2017) mengungkapkan bahwa pembelajaran 4.0 memberikan lebih banyak pengalaman lapangan. Lase (2019) lebih rinci mengungkapkan bahwa kemajuan teknologi memungkinkan pembelajaran domain tertentu secara efektif, sehingga memberi lebih 
banyak ruang untuk memperoleh keterampilan yang melibatkan pengetahuan siswa dan interaksi tatap muka. Dengan demikian, pengalaman lapangan akan diperdalam melalui kursus atau latihan-latihan. Berdasarkan dua pendapat tersebut maka dengan demikian perlu adanya penyesuaian dalam rancangan kurikulum pembelajaran sehingga siswa memperoleh lebih banyak pengalaman di lapangan seperti kegiatan magang atau proyek kolaborasi yang melibatkan pihak ketiga.

Adapun trend keenam menurut Fisk (2017) yakni interpretasi data. Kemampuan dan keterampilan siswa dalam mengolah, menganalisis, dan memprediksi data merupakan hal penting dalam proses pembelajaran. Pelaksanaan pembelajaran tidak hanya pada hafalan materi yang diberikan tapi lebih kepada pemahaman menyeluruh terhadap materi yang diberikan sehingga siswa dapat menginterpretasikan data menjadi sebuah kesimpulan berbasis data dan logika.

Lebih lanjut pada trens ketujuh Fisk (2017) membahas mengenai sistem penilaian pada pembelajaran 4.0, dimana penilaian akan beragam. Teknik penilaian konvensional misal dengan tanya jawab dianggap tidak relevan lagi pada pembelajaran 4.0, sehingga sumber penilaian diambil dari pengetahuan faktual, dan penerapan pengetahuan. Pengetahuan faktual dapat diperoleh selama proses pembelajaran berlangsung baik secara daring maupun tatap muka (blended learning), sementara untuk penilaian aplikasi pengetahuan dapat diambil dari pengerjaan proyek selama di lapangan. Trend kedelapan, ialah keterlibatan siswa dalam menentukan materi atau kurikulum dalam proses pembelajaran. Perbaharuan kurikulum mempertimbangkan pendapat siswa, sehingga kurikulum bersifat temporer, modern dan bernilai guna tinggi.

Trend kesembilan yang merupakan trend terakhir menurut Fisk (2017) adalah pendampingan atau mentoring. Kegiatan mentoring berpengaruh pada keberhasilan siswa dalam proses belajar, dimana guru berperan sebagai fasilitator yang akan mendampingi para siswa dalam setiap tahapan proses pembelajaran.

Pandangan Lase (2019) terhadap sembilan trend yang diungkapkan oleh Fisk (2019) yakni sebagai berikut:

Kesembilan pergeseran tren pendidikan 4.0 di atas menjadi tanggung jawab utama guru kepada peserta didik. Pendidik harus memainkan peran untuk mendukung transisi dan tidak menganggapnya sebagai ancaman bagi pengajaran konvensional. Ini merupakan tantangan yang menggairahkan, merangsang untuk bertindak, dan masif. Adaptasi terhadap tren pendidikan ini memberi garansi bagi individu dan masyarakat untuk mengembangkan serangkaian kompetensi, keterampilan, dan pengetahuan yang lebih lengkap dan mengeluarkan seluruh potensi kreatif mereka.

Pendapat Lase tersebut menitik beratkan pada bagaimana peranan guru dalam mengimplementasikan pendidikan 4.0, sehingga pembelajaran berbasis internet (daring) dapat terlaksana dengan baik. Namun dalam pernytaan tersebut perlu juga dicatat bahwa masa transisi memerlukan adaptasi yang memakan waktu dan pemikiran mendalam sehingga tujuan dan kompetensi pembelajaran dapat dicapai oleh siswa.

Disisi lain menghadapi perubahan pendidikan 4.0 merupakan tantangan tersendiri bagi pembelajaran seni tari, khususnya bagi sekolah atau pendidikan tinggi yang memiliki jurusan tersebut, contohnya Sekolah Menengah Kejuruan maupun Pendidikan Tinggi. Oleh sebab itu maka, pembahasan pembelajaran seni dalam menghadapi tantangan 4.0 dibatasi pada Sekolah Menengah Kejuruan Jurusan Seni tari dan Jurusan Pendidikan Seni Tari di Perguruan tinggi. Kedua lembaga tersebut memang memiliki konsentrasi terhadap kegiatan belajar mengajar dalam bidang seni tari dan menghasilkan lulusan yang memiliki kompetensi mempuni dalam menari(Noviyanti, 2017: 110), baik tarian tradisi (tari bentuk), maupun menciptakan tari baru (berkreasi dalam berolah gerak tari). 
Telahdipaparkandiatas bahwapembelajaran e-learning sepintas tidak terlihat kendala yang begitu serius, namun pada praktiknya dalam kegiatan belajar mengajar terdapat kendala yang cukup menjadi perhatian. Kendala yang dihadapi adalah sistem pembelajaran yang akan dilaksanakan dalam pembelajaran tari tradisi atau tari bentuk yang sudah ada dan memiliki kaidah atau aturan-aturan baku dalam gerak tarinya. Seperti yang kita tahu bahwa pembelajaran seni tari lebih bersifat praktikum mengolah keterampilan peserta didik dalam bergerak baik tari bentuk (tarian yang sudah ada) maupun tari hasil kreativitas. Pada proses pembelajaran tari kreasitivitas peserta didik memungkinkan untuk dilakukan pembelajaran secara daring karena pada mata pelajaran tersebut memberikan kebebasan kepada mahasiswa dalam mengekplorasi gerak. Selain itu pula karya yang dihasilkan dapat dibuat dalam bentuk $C D$ atau rekaman.

Berbeda halnya dengan pembelajaran tari bentuk atau tari tradisi yang sudah ada, di mana setiap gerak tari memiliki aturan baku tersendiri. Perkuliahan tari bentuk didominasi oleh metode pembelajaran demontrasi dan peniruan di mana tenaga pendidik mendemonstrasikan langsung gerak-gerak tariyangharus dikuasai oleh peserta didik. Sehingga aktivitas pembelajaran tidak memiliki kebebasan yang sama dalam berolah gerak, setiap peserta didik harus mengikuti setiap gerak dan aturannya sesuai dengan yang dicontohkan oleh tenaga pendidik. Pakem atau atauran aturan tersebut harus dilakukan dengan baik agar tarian yang dipelajarai atau dilakukan tidak kehilangan nilai dan ciri khasnya. Proses pembelajaran dikenal dengan istilah leraning by doing atau belajar dengan melakukannya langsung, sehingga peserta didik merasakan gerakan mana yg sudah betul dan masih harus diperbaiki.

Learning by doing di pembelajaran seni tari adalah metode pembelajaran yang mampu memberikan pemahaman dan pengetahuan yang menyeluruh mengenai gerak tari yang baik dan benar sesuai dengan aturan baku setiap tarian. Untuk mengetahui gerakan yang dilakukan sudah benar, maka perlu adanya kontak langsung antara pendidik dan peserta didik. Maksudnya, tidak hanya pada saat peserta didik mengikuti atau menirukan gerak, tapi juga terdapat kegiatan dimana tenaga pendidik memperbaiki, membenarkan sikap gerak yang dilakukan peserta didik secara langsung. Dengan adanya kontak fisik dalam pengertian perbaikan gerak secara langsung maka dapat langsung dirasakan oleh peserta didik aturan teknik gerak yang baik dan benar. Seperti yang diungkapkan oleh Jazuli (2016, hlm. 149) yang mengungkapkan bahwa pembelajaran merupakan proses interaksi antara peserta didik dengan pendidik dan sumber belajar pada suatu kondisi yang sengaja diciptakan agar terjadi perubahan tingkah laku. Adapun yang dimaksud tingkah laku pada pembahasan ini adalah sikap dan gerak dalam menari, sehingga peserta didik memiliki kecakapan atau keterampilan dalam membawakan tarian tersebut atau tarian lainnya.

Melalui proses inilah tenaga pendidik melakukan interaksi dan penilaian terhadap keterampilan gerak mahasiswa, sehingga apa yang dinilai benar-benar sesuai dengan kemampuannya saat menampilkan tarian (Sutiyono, 2017: 5). Apabila kegiatan tersebut dilakukan secara daring atau melalui media komputer dan internet maka dalam melakukan penilaian dirasa tidak akan maksimal karena para tenaga pendidik hanya melihat melalui video atau rekaman penampilan peserta didik. Para tenaga pendidik pun akan sulit mengoreksi gerakan yang dilakukan, karena tidak cukup dengan komentar atau kata-kata tanpa adanya koreksi sentuhan (fisik). Oleh sebab itu maka, untuk mendapatkan pemahaman yang matang tentang gerak yang benar sesuai aturan baku perlu dilakukan koreksi secara langsung bersentuhan (fisik) dengan mahasiswa.

Berdasarkan pemaparan di atas, maka beberapa hal tersebut harus diperhatikan dan dipersiapkan dengan matang apabila pembelajaran seni tari di sekolah khususnya di sekolah kejuruan dan perguruan tinggi dengan jurusan pendidikan seni tari dituntut untuk mengikuti era 4.0 saat ini. Sanusi (2014) mengungkapkan bahwa belajar bukan semata- 
mata mengikuti arus pertumbuhan hukum alami, melainkan justru mesti ada pilihan dan ijtihad tentang tujuan belajar, tentang content dan sumber belajar, tentang metode dan gaya belajar, tentang penilaian hasil belajar, dan tentang langkah lanjutan memanfaatkan hasil belajar yang satu dengan yang lainnya secara berkelanjutan. Berdasarkan pemamaparan tersebut, disimpulkan bahwa pembeajaran bukan berarti harus melulu mengikuti perkembangan zaman melainkan harus adanya peninjauan dan penyesuaian kembali terhadap konteks materi yang disampaikan.

Oleh sebab itu, pembelajaran berbasis daring atau e-learning harus melalui proses pemikiran dan persiapan yang matang mengenai materi dan aktivitas pembelajaran. Dengan demikian dapat menepis kekhawatiran tidak tersampaikannya materi dengan baik yang dapat berdampak pada capaian kompetensi yang diharapkan.

\section{KESIMPULAN}

Perubahan zaman secara tidak langsung memang menuntut perubahan diberbagai lini kehidupan untuk terus menyesuaikan diri dan berbenah diri, termasuk dunia pendidikan. Berbagai fasilitas kemudahan ditawarkan oleh perkembangan ilmu pengetahuan dan teknologi, namun kemudahan tersebut tentu perlu dipertimbangkan agar kompetensi yang diharapkan dalam sebuah pembelajaran tetap tersampaikan dan tercapai dengan baik. Penyesuaian karakter setiap mata pelajaran juga perlu dipertimbangkan, tidak sematamata mengikuti perubahan zaman tanpa pertimbangkan aspek yang lebih penting dari tujuan yang diharapkan, terlebih menyangkut nilai-nilai atau kaidah-kaidah local wisdom dalam tari. Pembelajaran seni tari khususnya perlu pemikiran, persiapan lebih matang dari sekedar mengejar dan mengimbangi era 4.0.

\section{DAFTAR PUSTAKA}

Fisk, Peter. 2017. Education 4.0 The Future of Leraning Will Be Dramatically Different, in School and Throught Life. [online] diunduh pada laman http://www.thegeniusworks. com/2017/01/future-education-youngeveryone-taught-together/

Ghufron, M.A. 2018. Revolusi Industi 4.0: Tantangan, Peluang, dan Solusi Bagi Dunia Pendidikan. Artikel Seminar Nasional dan Diskusi Panel Multidisiplin Hasil PPM. Jakarta, hlm 332-337.

Jazuli, M. 2016. Paradigma Pendidikan Seni. Semarang: CV. Farisma Indonesia

Lase,Delipiter.2019.PendidikandiEraRevolusi Industri 4.0. Artikel Jurnal Sundermann. Nias, hlm. 28-43. [online] diunduh pada laman http://doi.org/10.36588/sudermann. v1i1.18

Noviyanti, Siti Risa., Sutiyono, S. 2017. Bentuk, Perubahan Fungsi, dan Nilai-nilai Edukatif pada Musik Tari Japin Tahlul di Amuntai. Imaji: Jurnal Seni dan Pendidikan Seni, 15(1), 97-112.

Sanusi, Achmad. 2014. Pembaharuan Strategi Pendidikan (Filsafat, Manajemen, dan Arah Pembangunan Karakter Bangsa. Bandung: Nuansa Cendekia.

Susilawati, Lusi., Sutiyono, S. 2017. Evaluasi Pelaksanaan Kurokulum 2013 Pada Mata Pelajaran Seni Tari. Imaji: Jurnal Seni dan Pendidikan Seni, 15(2), 126- 139.

Sutiyono. S. 2017. Art Attractions As Media of Learning to Have a Meaningful Learning. Journal of Management Sciences \& Education Vol. 6(3), 1-8.

Tjadrawina, R.R. 2016. Industri 4.0: Revolusi indutri abad ini dan Pengaruhnya Pada Bidang Kesehatan dan Bioteknologi. Jurnal Medicinus, Vol 29, Nomor 1, Edisi April

Trilling, B \& Fade, C. 2009. $21^{\text {st }}$-CenturySkills: Learning for Life in Our Times. US: JosseyBass A Wiley Imprint. 